\title{
Highly Efficient and Facile Method for Synthesis of 2-Substituted Benzimidazoles via Reductive Cyclization of $O$-Nitroaniline and Aryl Aldehydes
}

\author{
Hossein Naeimi and Nasrin Alishahi \\ Department of Organic Chemistry, Faculty of Chemistry, University of Kashan, Kashan 87317, Iran \\ Correspondence should be addressed to Hossein Naeimi, naeimi@kashanu.ac.ir \\ Received 15 August 2012; Accepted 14 October 2012 \\ Academic Editor: Paul Watts
}

Copyright (C) 2012 H. Naeimi and N. Alishahi. This is an open access article distributed under the Creative Commons Attribution License, which permits unrestricted use, distribution, and reproduction in any medium, provided the original work is properly cited.

A versatile and convenient synthesis of 2 -substituted benzimidazoles, using $o$-nitroaniline as starting material with several aryl aldehydes, has been accomplished by using a small amount of a reluctant agent. The reaction was carried out under very mild conditions at room temperature. The yields obtained are very good in reasonably short reaction times.

\section{Introduction}

Benzimidazoles are very useful intermediates/subunits for the development of molecules of pharmaceutical or biological interest. Substituted benzimidazole derivatives have found applications in diverse therapeutic areas including antihypertensives, antivirals, antifungals, anticancers, and antihistaminics [1]. There are two general methods for the synthesis of 2-substituted benzimidazole. One is coupling of $o$-phenylenediamines and carboxylic acids [2] or their derivatives (nitriles, imidates, or orthoesters) [3], which often require strong acidic conditions, and sometimes combine with very high temperature or the use of microwave irradiation [4]. The other way involves a two-step procedure that is oxidative cyclodehydrogenation of aniline schiff's bases, which are often generated in situ from the condensation of $o$-phenylenediamines and aldehydes. Various oxidative reagents such as tetracyano ethylene [5], nitrobenzene [6], 1,4-benzoquinone [7], DDQ [8], benzofuroxan [9], $\mathrm{NaHSO}_{3}[10], \mathrm{MnO}_{2}$ [11], oxone [12], DMP [13], $\mathrm{Pb}(\mathrm{OAc})_{4}$ [14], and $\mathrm{NH}_{4} \mathrm{VO}_{3}$ [15] have been employed. However, all of these methods have problems, including drastic reaction conditions, expensive catalyst, low yields, and severe side-reactions. Therefore, the development of a cost-effective, safe, and inexpensive reagent system is desirable.

In this research, we report a one-pot, high-yield, facile, and inexpensive synthesis of 2-substituted benzimidazoles directly from $o$-nitroanilines and aryl aldehydes via reductive condensation of $o$-nitroanilines at room temperature under mild conditions.

\section{Experimental Section}

2.1. Materials. All the materials were of commercial reagent grade. The aromatic aldehydes and $o$-nitroaniline were purified by standard procedures and purity determined by thin layer chromatography (TLC).

2.2. Apparatus. IR spectra were recorded as $\mathrm{KBr}$ pellets on a Perkin-Elmer 781 spectrophotometer and an Impact 400 Nicolet FT-IR spectrophotometer. ${ }^{1} \mathrm{H}$ NMR and ${ }^{13} \mathrm{C}$ NMR were recorded in DMSO solvent on a Bruker DRX-400 spectrometer with tetramethylsilane as internal reference. Melting points obtained with a Yanagimoto micromelting point apparatus are uncorrected. The purity determination of the substrates and reaction monitoring were accomplished 
by TLC on silica-gel polygram SILG/UV 254 plates (from Merck Company).

2.3. General Experimental Procedure for the Tandem Reaction. This procedure was used for the synthesis of most of the compounds listed in Table 1. A solution of $o$-nitroaniline $(0.138 \mathrm{~g}, 1.0 \mathrm{mmol})$ and aryl aldehyde $(1.0 \mathrm{mmol})$ in $\mathrm{EtOH}$ $(4 \mathrm{~mL})$ was prepared. Then $1 \mathrm{M}$ aq $\mathrm{Na}_{2} \mathrm{~S}_{2} \mathrm{O}_{4}(0.522 \mathrm{gr}$, $3.0 \mathrm{mmol}$ ) was added, and the mixture was stirred at room temperature for the time indicated in Table 1. The progress of the reaction was monitored by TLC. After completion of the reaction, the resulting solution was poured into icewater mixture and filtered off, washed with cold water, the crude product was obtained as a solid. The solid product was recrystallized from methanol, and the pure 2-substituted benzimidazole was yielded. The corresponding products were identified by physical and spectroscopic data.

2-Phenyl-benzimidazole (2a) $\left(\mathrm{C}_{13} \mathrm{H}_{10} \mathrm{~N}_{2}\right)$. Pale yellow solid; $\mathrm{m} . \mathrm{p}=289-290^{\circ} \mathrm{C}\left(\mathrm{m} \cdot \mathrm{p}=288-290^{\circ} \mathrm{C}\right)[16] ; \mathrm{IR}(\mathrm{KBr}) / \nu$ $\left(\mathrm{cm}^{-1}\right) 3446(\mathrm{NH}), 1622(\mathrm{C}=\mathrm{N}), 1590,1445(\mathrm{C}=\mathrm{C}, \mathrm{Ar}) ;{ }^{1} \mathrm{H}$ NMR (DMSO, $400 \mathrm{MHz}) / \delta$ ppm: $7.19(2 \mathrm{H}, \mathrm{m}, \mathrm{Ar}), 7.48-$ $7.64(5 \mathrm{H}, \mathrm{m}, \mathrm{Ar}), 8.17(2 \mathrm{H}, \mathrm{m}, \mathrm{Ar}), 12.9(1 \mathrm{H}, \mathrm{s}, \mathrm{NH}) ;{ }^{13} \mathrm{C}$ NMR (100 MHz, DMSO)/ $\delta$ ppm: 111.1, 118.6, 121.9, 126.2, 128.6, 129.5, 130.0, 134.8, 143.5, 151.0; MS: $m / z: 193(\mathrm{M}-\mathrm{H}$, $100 \%)$.

2-(2,3-Dicholorophenyl)-benzimidazole (2b) $\left(\mathrm{C}_{13} \mathrm{H}_{8} \mathrm{Cl}_{2} \mathrm{~N}_{2}\right)$. Yellow solid; $\mathrm{m} . \mathrm{p}=224-226^{\circ} \mathrm{C}$ [17]; IR $(\mathrm{KBr}) / \nu\left(\mathrm{cm}^{-1}\right) 3095$ $(\mathrm{NH}), 1624(\mathrm{C}=\mathrm{N}), 1540,1433(\mathrm{C}=\mathrm{C}, \mathrm{Ar}) ;{ }^{1} \mathrm{H}$ NMR (DMSO, $400 \mathrm{MHz}) / \delta$ ppm: $7.2(2 \mathrm{H}, \mathrm{m}, \mathrm{Ar}), 7.53(1 \mathrm{H}, \mathrm{m}, \mathrm{Ar}), 7.64$ $(2 \mathrm{H}, \mathrm{m}, \mathrm{Ar}), 7.82(2 \mathrm{H}, \mathrm{m}, \mathrm{Ar}), 12.8(1 \mathrm{H}, \mathrm{s}, \mathrm{NH}) ;{ }^{13} \mathrm{C} \mathrm{NMR}$ $(100 \mathrm{MHz}, \mathrm{DMSO}) / \delta$ ppm: 115.93, 122.90, 128.91, 130.53, $131.27,132.12,132.89,133.23,139.30,149.08$.

2-(4-Methylphenyl)-benzimidazole (2c) $\left(\mathrm{C}_{14} \mathrm{H}_{12} \mathrm{~N}_{2}\right)$. White solid; $\mathrm{m} . \mathrm{p}=260-261^{\circ} \mathrm{C},\left(\mathrm{m} \cdot \mathrm{p}=261-263^{\circ} \mathrm{C}\right)[18] ; \mathrm{IR}(\mathrm{KBr}) / \nu$ $\left(\mathrm{cm}^{-1}\right) 3429(\mathrm{NH}), 1620(\mathrm{C}=\mathrm{N}), 1587,1433(\mathrm{C}=\mathrm{C}, \mathrm{Ar}) ;{ }^{1} \mathrm{H}$ NMR (DMSO, $400 \mathrm{MHz}) / \delta$ ppm: $2.36(3, \mathrm{~s}, \mathrm{Me}) 7.18(2 \mathrm{H}$, $\mathrm{m}, \mathrm{Ar}, J=3.2 \mathrm{~Hz}), 7.34(2 \mathrm{H}, \mathrm{d}, \mathrm{Ar}, J=8 \mathrm{~Hz}), 7.57(2 \mathrm{H}, \mathrm{m}$, $\mathrm{Ar}, J=3.2 \mathrm{~Hz}), 8.06(2 \mathrm{H}, \mathrm{d}, \mathrm{Ar}, J=8 \mathrm{~Hz}), 12.8(1 \mathrm{H}, \mathrm{s}, \mathrm{NH})$; ${ }^{13} \mathrm{C}$ NMR $(100 \mathrm{MHz}, \mathrm{DMSO}) / \delta \mathrm{ppm:} 21.41,115.50,122.43$, $125.89,127.93,129.97,139,140.03,151.90$.

2-(4-Boromophenyl)-benzimidazole (2d) $\left(\mathrm{C}_{13} \mathrm{H}_{9} \mathrm{BrN}_{2}\right)$. Pale yellow solid; m.p $=292-293^{\circ} \mathrm{C}\left(\mathrm{m} \cdot \mathrm{p}=250-252^{\circ} \mathrm{C}\right)$ [19]; IR $(\mathrm{KBr}) / \nu\left(\mathrm{cm}^{-1}\right) 3449(\mathrm{NH}), 1628(\mathrm{C}=\mathrm{N}), 1598,1456(\mathrm{C}=\mathrm{C}$, $\mathrm{Ar}) ;{ }^{1} \mathrm{H}$ NMR (DMSO, $\left.400 \mathrm{MHz}\right) / \delta \mathrm{ppm}: 7.53(2 \mathrm{H}, \mathrm{m}, \mathrm{Ar}$, $J=8.2 \mathrm{~Hz}), 7.83(2 \mathrm{H}, \mathrm{m}, \mathrm{Ar}, J=8.2 \mathrm{~Hz}), 7.95(2 \mathrm{H}, \mathrm{d}$, Ar, $J=4.8 \mathrm{~Hz}), 8.28(2 \mathrm{H}, \mathrm{d}, \mathrm{Ar}, J=4.8 \mathrm{~Hz}) ;{ }^{13} \mathrm{C} \mathrm{NMR}$ $(100 \mathrm{MHz}, \mathrm{DMSO}) / \delta$ ppm: 102.5, 121.5, 141.6, 127, 128.1, $130.4,138.2,150.2$.

2-(2-Cholorophenyl)-benzimidazole (2e) $\left(\mathrm{C}_{13} \mathrm{H}_{9} \mathrm{ClN}_{2}\right)$. Yellow solid; m.p $=231-233^{\circ} \mathrm{C},\left(\mathrm{m} \cdot \mathrm{p}=232-234^{\circ} \mathrm{C}\right)[18]$; IR $(\mathrm{KBr}) / \nu\left(\mathrm{cm}^{-1}\right) 3444(\mathrm{NH}), 1591(\mathrm{C}=\mathrm{N}), 1575,1440$ $(\mathrm{C}=\mathrm{C}, \mathrm{Ar}) ;{ }^{1} \mathrm{H}$ NMR (DMSO, $\left.400 \mathrm{MHz}\right) / \delta \mathrm{ppm}: 7.2(2 \mathrm{H}$, m, Ar), 7.50-7.89 (6H, m, Ar), $12.9(1 \mathrm{H}, \mathrm{s}, \mathrm{NH}) ;{ }^{13} \mathrm{C}$ NMR
(100 MHz, DMSO)/ $\delta$ ppm: 116.02, 122.72, 127.87, 130.40, $130.80,131.64,132.16,132.54,139.50,149.64 ;$ MS: $m / z$ : $228.5(\mathrm{M}+)$.

2-(4-Cholorophenyl)-benzimidazole (2f) $\left(\mathrm{C}_{13} \mathrm{H}_{9} \mathrm{ClN}_{2}\right)$. Yellow solid; m.p $=290-291^{\circ} \mathrm{C},\left(\mathrm{m} \cdot \mathrm{p}=291-293^{\circ} \mathrm{C}\right)$ [20]; IR $(\mathrm{KBr}) / \nu\left(\mathrm{cm}^{-1}\right) 3442(\mathrm{NH}), 1598(\mathrm{C}=\mathrm{N}), 1580,1429(\mathrm{C}=\mathrm{C}$, Ar); ${ }^{1} \mathrm{H}$ NMR (DMSO, $\left.400 \mathrm{MHz}\right) / \delta$ ppm: $7.2(2 \mathrm{H}, \mathrm{m}, \mathrm{Ar})$, 7.50-7.89 (6H, m, Ar), $13(1 \mathrm{H}, \mathrm{s}, \mathrm{NH}) ;{ }^{13} \mathrm{C}$ NMR $(100 \mathrm{MHz}$, DMSO $/ \delta$ ppm: $113.5,123.7,127.6,128.3,129.4,133.4$, 138.9, 151.8; MS: $m / z: 229.0(\mathrm{M}+\mathrm{H})+$.

2-(2-Hydroxyphenyl)-benzimidazole (2g) $\quad\left(\mathrm{C}_{13} \mathrm{H}_{10} \mathrm{~N}_{2} \mathrm{O}\right)$. White solid; $\mathrm{m} \cdot \mathrm{p}=238-240^{\circ} \mathrm{C}\left(\mathrm{m} \cdot \mathrm{p}=240-242^{\circ} \mathrm{C}\right)[21]$; IR $(\mathrm{KBr}) / \nu\left(\mathrm{cm}^{-1}\right) 3325(\mathrm{OH}), 3055(\mathrm{NH}), 1593(\mathrm{C}=\mathrm{N})$, 1530, $1491(\mathrm{C}=\mathrm{C}, \mathrm{Ar}) ;{ }^{1} \mathrm{H}$ NMR (DMSO, $\left.400 \mathrm{MHz}\right) / \delta \mathrm{ppm}$ : 6.99-7.05 (2H, m, Ar, $J=8 \mathrm{~Hz}), 7.27(2 \mathrm{H}, \mathrm{m}, \mathrm{Ar}, J=8 \mathrm{~Hz})$, $7.37(1 \mathrm{H}, \mathrm{t}, \mathrm{Ar}), 7.66(2 \mathrm{H}, \mathrm{m}, \mathrm{Ar}), 8.06(1 \mathrm{H}, \mathrm{d}, \mathrm{Ar}), 13.19$ $(1 \mathrm{H}, \mathrm{s}, \mathrm{OH}), 13.19(1 \mathrm{H}, \mathrm{s}, \mathrm{NH}) ;{ }^{13} \mathrm{C}$ NMR $(100 \mathrm{MHz}$, DMSO)/ $\delta$ ppm: 112.10, 113.11, 117.67, 119.56, 123.26, 126.68, 132.16, 141.21, 152.22, 158.56; MS: $m / z: 210(\mathrm{M}+)$.

2-(3-Hydroxyphenyl)-benzimidazole (2h) $\left(\mathrm{C}_{13} \mathrm{H}_{10} \mathrm{~N}_{2} \mathrm{O}\right)$. Yellow solid; m.p $=245-247^{\circ} \mathrm{C}$ [17]; $\mathrm{IR}(\mathrm{KBr}) / \nu\left(\mathrm{cm}^{-1}\right) 3434$ $(\mathrm{OH}), 3243(\mathrm{NH}), 1588(\mathrm{C}=\mathrm{N}), 1541,1445(\mathrm{C}=\mathrm{C}, \mathrm{Ar}) ;{ }^{1} \mathrm{H}$ NMR (DMSO, $400 \mathrm{MHz}) / \delta$ ppm: $6.9(1 \mathrm{H}, \mathrm{d}, \mathrm{Ar}), 7.18(2 \mathrm{H}$, m, Ar), $7.33(1 \mathrm{H}, \mathrm{t}, \mathrm{Ar}), 7.59$ (4H, d, Ar), 12.9 (1H, s, NH); ${ }^{13} \mathrm{C}$ NMR (DMSO, $\left.100 \mathrm{MHz}\right) / \delta$ ppm: $113.93,115.55,117.55$, $117.80,122.59,130.51,131.86,139.87,151.93,158.30$.

2-(4-Hydroxyphenyl)-benzimidazole (2i) $\left(\mathrm{C}_{13} \mathrm{H}_{10} \mathrm{~N}_{2} \mathrm{O}\right)$. White solid; $\mathrm{m} . \mathrm{p}=254-255^{\circ} \mathrm{C}\left(\mathrm{m} . \mathrm{p}=254.1-256.6^{\circ} \mathrm{C}\right)[22]$; IR $(\mathrm{KBr}) / \nu\left(\mathrm{cm}^{-1}\right) 3383(\mathrm{OH}), 3202(\mathrm{NH}), 1668(\mathrm{C}=\mathrm{N})$, 1600, $1457(\mathrm{C}=\mathrm{C}, \mathrm{Ar}) ;{ }^{1} \mathrm{H}$ NMR (DMSO, $\left.400 \mathrm{MHz}\right) / \delta \mathrm{ppm}$ : 6.91-7.50 (4H, m, Ar), 7.73-8.21 (4H, m, Ar), $9.7(1 \mathrm{H}, \mathrm{s}$, $\mathrm{OH}), 15.2(1 \mathrm{H}, \mathrm{s}, \mathrm{NH}) ;{ }^{13} \mathrm{C}$ NMR $(100 \mathrm{MHz}, \mathrm{DMSO}) / \delta$ ppm: $113.06,114.04,116.83,126.03,131.62,132,149.93$, 160.71.

2-(3-Methoxyphenyl)-benzimidazole (2j) $\left(\mathrm{C}_{14} \mathrm{H}_{12} \mathrm{~N}_{2} \mathrm{O}\right)$. Yellow solid; m.p $=200-202^{\circ} \mathrm{C}\left(\mathrm{m} . \mathrm{p}=205-206^{\circ} \mathrm{C}\right)$ [19]; IR $(\mathrm{KBr}) / \nu\left(\mathrm{cm}^{-1}\right) 3437(\mathrm{NH}), 1596(\mathrm{C}=\mathrm{N}), 1541,1464(\mathrm{C}=\mathrm{C}$, Ar); ${ }^{1} \mathrm{H}$ NMR (DMSO, $\left.400 \mathrm{MHz}\right) / \delta$ ppm: $3.9(3 \mathrm{H}, \mathrm{s}, \mathrm{Me})$, $7.05(1 \mathrm{H}, \mathrm{m}, \mathrm{Ar}), 7.19(2 \mathrm{H}, \mathrm{m}, \mathrm{Ar}), 7.45(1 \mathrm{H}, \mathrm{s}, \mathrm{Ar}), 7.59$ $(2 \mathrm{H}, \mathrm{m}, \mathrm{Ar}, J=8 \mathrm{~Hz}), 7.74(2 \mathrm{H}, \mathrm{m}, \mathrm{Ar}, J=8 \mathrm{~Hz})$, $12.9(1 \mathrm{H}, \mathrm{s}, \mathrm{NH}) ;{ }^{13} \mathrm{C}$ NMR $(100 \mathrm{MHz}, \mathrm{DMSO}) / \delta \mathrm{ppm}$ : $56.01,114.03,115.25,116.50,117.80,124.49,130.47,132.63$, $138.99,152.23,159.10$.

2-(2,5-Dimethoxyphenyl)-benzimidazole (2k) $\left(\mathrm{C}_{15} \mathrm{H}_{14} \mathrm{~N}_{2} \mathrm{O}_{2}\right)$. Yellow solid; m.p. $197-198^{\circ} \mathrm{C}$ [17]; IR $(\mathrm{KBr}) / \nu\left(\mathrm{cm}^{-1}\right) 3408$ $(\mathrm{NH}), 1622(\mathrm{C}=\mathrm{N}), 1511,1458(\mathrm{C}=\mathrm{C}, \mathrm{Ar}) ;{ }^{1} \mathrm{H}$ NMR (DMSO, $400 \mathrm{MHz}) / \delta$ ppm: 4.02 (3H, s, Me), 3.85 (3H, s, Me) 7.33 $(2 \mathrm{H}, \mathrm{d}, \mathrm{Ar}), 7.55(2 \mathrm{H}, \mathrm{m}, \mathrm{Ar}), 7.89(2 \mathrm{H}, \mathrm{m}, \mathrm{Ar}), 8.02(1 \mathrm{H}$, s, Ar), 15 (1H, s, NH); ${ }^{13} \mathrm{C}$ NMR (DMSO, $\left.100 \mathrm{MHz}\right) / \delta$ ppm: $56.69,57.05,11.24,114.41,114.55,114.65,122.19,126.30$, $131.68,146.07,152.58,153.72$. 
TABLE 1: Reaction of various aryl aldehydes with $o$-nitroaniline.

\begin{tabular}{|c|c|c|c|c|}
\hline Entry & $\begin{array}{c}\text { Substrate } \\
\text { Ar }\end{array}$ & Product $^{\mathrm{a}}$ & Time (hour) & Yield $(\%)^{b}$ \\
\hline 1 & & $2 a$ & 2 & 95 \\
\hline 2 & & $2 b$ & 1.8 & 95 \\
\hline 3 & & $2 c$ & 2 & 94 \\
\hline 4 & & $2 d$ & 1.8 & 92 \\
\hline 5 & & $2 e$ & 2.2 & 91 \\
\hline 6 & & $2 f$ & 1.5 & 94 \\
\hline 7 & & $2 \mathrm{~g}$ & 1.8 & 90 \\
\hline 8 & & $2 \mathrm{~h}$ & 1.7 & 93 \\
\hline 9 & & $2 \mathbf{i}$ & 1.8 & 91 \\
\hline 10 & & $2 j$ & 1.6 & 92 \\
\hline 11 & & $2 \mathrm{k}$ & 1.2 & 94 \\
\hline 12 & & 21 & 1.9 & 91 \\
\hline 13 & & $2 \mathrm{~m}$ & 1.7 & 92 \\
\hline
\end{tabular}

all compounds are known, and their physical and spectroscopic data were in good agreement with those of authentic samples.

bYields refer to pure isolated products.

2-(4-Methoxyphenyl)-benzimidazole (2l) $\left(\mathrm{C}_{14} \mathrm{H}_{12} \mathrm{~N}_{2} \mathrm{O}\right)$. Yellow solid; $\mathrm{m} . \mathrm{p}=229-230^{\circ} \mathrm{C},\left(\mathrm{m} . \mathrm{p}=229.2-231.1^{\circ} \mathrm{C}\right)$ [22]; IR $(\mathrm{KBr}) / \nu\left(\mathrm{cm}^{-1}\right) 3344(\mathrm{NH}), 1608(\mathrm{C}=\mathrm{N}), 1506,1461(\mathrm{C}=\mathrm{C}$, $\mathrm{Ar}) ;{ }^{1} \mathrm{H}$ NMR (DMSO, $\left.400 \mathrm{MHz}\right) / \delta \mathrm{ppm}: 3.89$ (3H, s, Me), $7.2(2 \mathrm{H}, \mathrm{d}, \mathrm{Ar}, J=8 \mathrm{~Hz}), 7.52(2 \mathrm{H}, \mathrm{m}, \mathrm{Ar}, J=4 \mathrm{~Hz}), 7.79$ $(2 \mathrm{H}, \mathrm{m}, \mathrm{Ar}, J=4 \mathrm{~Hz}), 8.38(2 \mathrm{H}, \mathrm{d}, \mathrm{Ar}, J=8 \mathrm{~Hz}), 15.3(1 \mathrm{H}$, s, NH); ${ }^{13} \mathrm{C}$ NMR (DMSO, $\left.100 \mathrm{MHz}\right) / \delta$ ppm: 56.24, 114.06, $115.34,115.53,126.03,130.62,132,148.91,163.61$.

2-(N,N-Dimethylphenyl)-benzimidazole (2m) $\left(\mathrm{C}_{15} \mathrm{H}_{15} \mathrm{~N}_{3}\right)$. Yellow solid; $\mathrm{m} . \mathrm{p}=277-279^{\circ} \mathrm{C}\left(\mathrm{m} . \mathrm{p}=294.2-296.3^{\circ} \mathrm{C}\right)$ [22]; IR $(\mathrm{KBr}) / \nu\left(\mathrm{cm}^{-1}\right) 3391(\mathrm{NH}), 1605(\mathrm{C}=\mathrm{N}), 1518,1459$ 


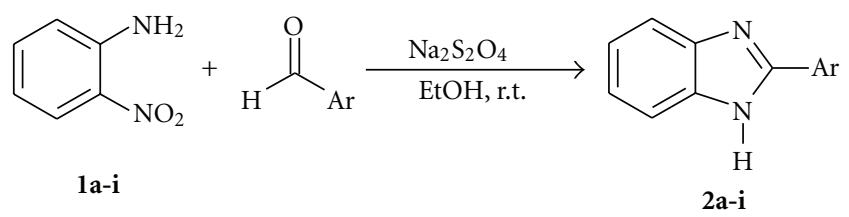

Scheme 1: Synthesis of 2-substituted benzimidazoles from $o$-nitroanilines and aryl aldehydes via an in situ nitro reduction.

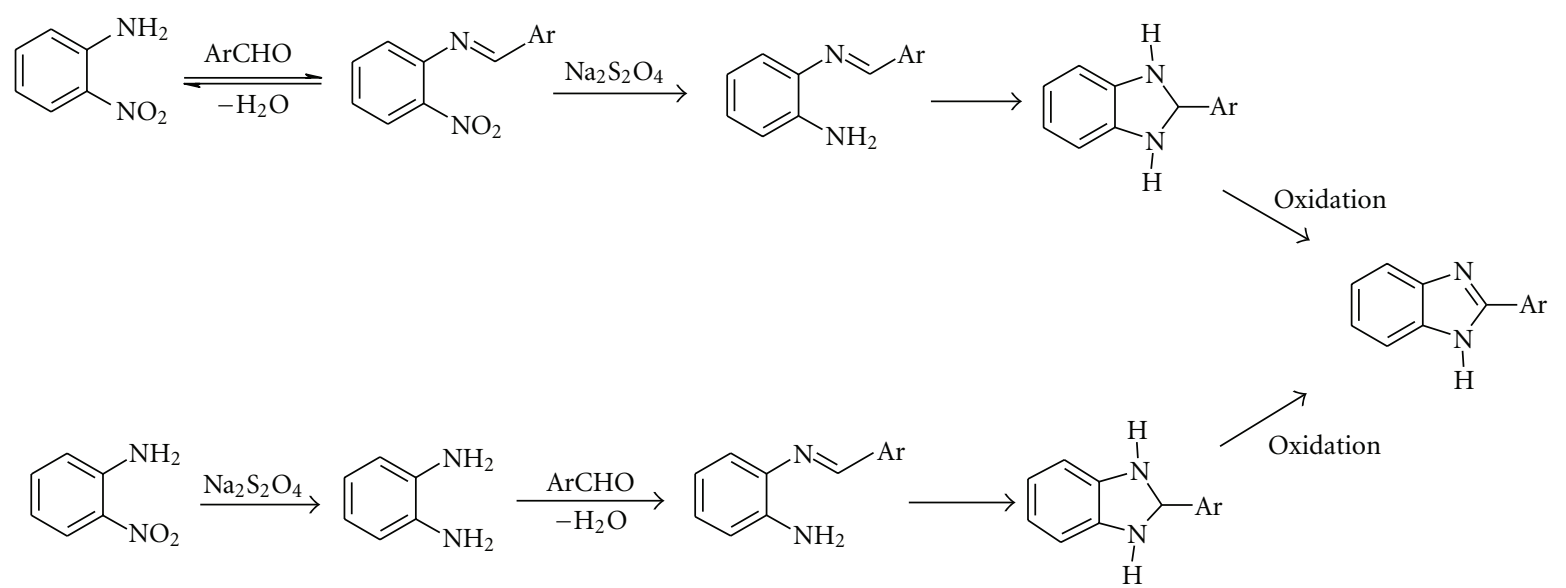

Scheme 2: Possible mechanism and tentative intermediates in the synthesis of benzimidazoles.

$(\mathrm{C}=\mathrm{C}, \mathrm{Ar}) ;{ }^{1} \mathrm{H}$ NMR $(\mathrm{DMSO}, 400 \mathrm{MHz}) / \delta \mathrm{ppm}: 6.84(2 \mathrm{H}, \mathrm{d}$, $\mathrm{Ar}, J=7.8 \mathrm{~Hz}), 7.43(2 \mathrm{H}, \mathrm{m}, \mathrm{Ar}, J=4 \mathrm{~Hz}), 7.70(2 \mathrm{H}, \mathrm{m}, \mathrm{Ar}$, $J=4 \mathrm{~Hz}), 8.21(2 \mathrm{H}, \mathrm{d}, \mathrm{Ar}, J=7.8 \mathrm{~Hz}), 15.2(1 \mathrm{H}, \mathrm{s}, \mathrm{NH}) ;{ }^{13} \mathrm{C}$ NMR (DMSO, $100 \mathrm{MHz}) / \delta$ ppm: 39.5, 107.8, 111.8, 113.2, $125.1,129.1,131.5,149.8,153.2$.

\section{Results and Discussion}

In order to synthesis of 2-substituted benzimidazoles, $o$ nitroanilines and aryl aldehydes were reacted together in mole ratio $1: 1$ in the presence of sodium dithionite at room temperature (Scheme 1). In this reaction, the corresponding benzimidazoles were obtained as benefit and significant products.

We have studied the different reaction conditions on model reaction. The results revealed that, when the reaction was carried out at room temperature, it has got the excellent yields of product in short reaction times. We hypothesized that the formation of the 2-substituted benzimidazoles could be achieved by two mechanisms (Scheme 2).

In order to test our initial hypothesis postulating a rather controlled aryl nitro reduction during the reductive cyclization step and in order to explain the observed reaction outcome, it was attempted some comparison experiments with two different routes which have been widely used in the aryl nitro group reduction. When the reaction between $o$ nitroaniline and 4-methylbenzaldehyde was conducted, the desired monosubstituted benzimidazole was generated as the sole product in high yield. On the contrary, when the same reaction was subjected to the $\mathrm{Na}_{2} \mathrm{~S}_{2} \mathrm{O}_{4}$ conditions, a mixture of monosubstituted and 1,2-disubstituted benzimidazoles was formed with the disubstituted analog as the major component.

In order to ascertain the limitation of the reaction, the reaction of $o$-nitro aniline with several aryl aldehydes in the presence of sodium dithionite was occurred. The obtained results are indicated in Table 1 . As can be seen in this table, the reaction with all aryl aldehydes, the 2-substituted benzimidazoles were obtained in excellent yields as only product and short reaction times. It seems that the order of addition of substrates together influenced on the quality and yield of the reaction product.

The structure of products has been confirmed by physical and spectroscopic data such as IR, ${ }^{1} \mathrm{H} \mathrm{NMR}$, and ${ }^{13} \mathrm{C}$ NMR. In the IR spectra, the stretching frequency of aromatic $\mathrm{C}=\mathrm{C}$ is formed in the region between $v=1429-1600 \mathrm{~cm}^{-1}$. The stretching vibration of $\mathrm{C}-\mathrm{H}$ in the alkyl groups appeared at region between $v=2903-3059 \mathrm{~cm}^{-1}$. In the ${ }^{1} \mathrm{H} \mathrm{NMR}$ spectra, one proton of $\mathrm{N}-\mathrm{H}$ has chemical shift in $\delta=12.72-$ $15.2 \mathrm{ppm}$. The signals around $\delta=6.84-8.38$ are assigned by protons of $\mathrm{CH}=\mathrm{CH}$ of aromatic rings. In the ${ }^{13} \mathrm{C} \mathrm{NMR}$ spectra, the carbon of $\mathrm{C}=\mathrm{N}$ has chemical shift in $\delta=148.9-$ 151 ppm.

\section{Conclusion}

In this study, we have developed an efficient method for the synthesis of benzimidazoles and other derivatives. Using of $\mathrm{Na}_{2} \mathrm{~S}_{2} \mathrm{O}_{4}$ as a highly efficient, inexpensive, easy handling, and nontoxic reducing reagent makes the present procedure ecofriendly and economically acceptable. Furthermore, high yields of products, short reaction times, mild reaction 
conditions, and easy workup are other noteworthy advantages which make this method a valid contribution to the existing methodologies.

\section{Acknowledgment}

The authors are grateful to University of Kashan for supporting this work by Grant no. 159148/7.

\section{References}

[1] G. L. Gravatt, B. C. Baguley, W. R. Wilson, and W. A. Denny, "DNA-directed alkylating agents. 6. Synthesis and antitumor activity of DNA minor groove-targeted aniline mustard analogues of pibenzimol (Hoechst 33258)," Journal of Medicinal Chemistry, vol. 37, no. 25, pp. 4338-4345, 1994.

[2] M. R. Grimmet, A. R. Katritzky, and C. W. Rees, Reactivity of five-membered rings with two or more heteroatoms, vol. 5, chapter 4. 02, Comprehensive Heterocyclic Chemistry Pergamon Press, Oxford, UK, 1984.

[3] A. Czarny, W. D. Wilson, and D. W. Boykin, "Synthesis of mono-cationic and dicationic analogs of Hoechst 33258," Journal of Heterocyclic Chemistry, vol. 33, no. 4, pp. 1393-1397, 1996.

[4] K. Bougrin, A. Loupy, and M. Soufiaoui, "Three new ways to synthesize 1,3-azole derivatives by microwaves," Tetrahedron, vol. 54, no. 28, pp. 8055-8064, 1998.

[5] H. Chikashita, S. Nishida, M. Miyazaki, and Y. K. Morita-Itoh, "In situ generation and synthetic application of 2-phenylbenzimidazoline to the selective reduction of carbon-carbon double bonds of electron-deficient olefins," Bulletin of the Chemical Society of Japan, vol. 60, no. 2, pp. 737-746, 1987.

[6] R. S. Harapanhalli, L. W. McLaughlin, R. W. Howell, D. V. Rao, S. J. Adelstein, and A. I. Kassis, "[125I/127I]iodoHoechst 33342: synthesis, DNA binding, and biodistribution," Journal of Medicinal Chemistry, vol. 39, no. 24, pp. 4804-4809, 1996.

[7] S. Kumar, V. Kansal, and A. Bhaduri, "A one pot microwave promoted synthesis of 2-aryl-1H-benzimidazole using sodium hydrogen sulfite," Indian Journal of Chemistry, vol. 20, p. 254, 1991.

[8] K. J. Lee and K. D. Janda, "Traceless solid-phase synthesis of 5benzoylbenzimidazoles," Canadian Journal of Chemistry, vol. 79, no. 11, pp. 1556-1561, 2001.

[9] F. Patzold, F. Zeuner, T. Heyer, and H. J. Niclas, "Dehydrogenations using benzofuroxan as oxidant," Synthetic Communications, vol. 22, no. 2, pp. 281-288, 1992.

[10] S. C. Austen and J. M. Kane, "A short synthesis of the PARP inhibitor 2-(4-trifluoro-methylphenyl)benzimidazole4-carboxamide (NU1077)," Journal of Heterocyclic Chemistry, vol. 38, no. 4, pp. 979-980, 2001.

[11] I. Bhatnagar and M. V. George, "Oxidation with metal oxidesII. Oxidation of chalcone phenylhydrazones, pyrazolines, oaminobenzylidine anils and o-hydroxy benzylidine anils with manganese dioxide," Tetrahedron, vol. 24, no. 3, pp. 12931298, 1968.

[12] P. L. Beaulieu, B. Haché, and E. Von Moos, "A practical oxone ${ }^{\circledR}$-Mediated, high-throughput, solution-phase synthesis of benzimidazoles from 1,2-phenylenediamines and aldehydes and its application to preparative scale synthesis," Synthesis, vol. 11, pp. 1683-1692, 2003.

[13] S. K. Dabhade, R. O. Bora, M. Farooqui, and C. H. Gill, "DMP (1,1,1-Triacetoxy-1,1-dihydro-1,2-benziodoxol-3(1H)-one): a novel catalyst for synthesis of 2 -substituted benzimidazoles derivatives," Chinese Chemical Letters, vol. 20, no. 8, pp. 893$897,2009$.

[14] F. F. Stephens and J. D. Bower, "The preparation of benziminazoles and benzoxazoles from Schiff's bases-part I," Journal of the Chemical Society, pp. 2971-2972, 1949.

[15] G. R. Jadhav, M. U. Shaikh, R. P. Kale, and C. H. Gill, "Ammonium metavanadate: a novel catalyst for synthesis of 2substituted benzimidazole derivatives," Chinese Chemical Letters, vol. 20, no. 3, pp. 292-295, 2009.

[16] R. R. Nagawade and D. B. Shinde, " $\mathrm{BF}_{3} \cdot \mathrm{OEt}_{2}$ promoted solvent-free synthesis of benzimidazole derivatives," Chinese Chemical Letters, vol. 17, p. 453, 2006.

[17] H. Naeimi and N. Alishahi, "A simple, mild and efficient onepot synthesis of 2-substituted benzimidazoles in the presence of $\mathrm{H}_{2} \mathrm{O}_{2} / \mathrm{HCl}$ under microwave irradiation," Journal of the Chinese Chemical Society, vol. 59, no. 8, pp. 1001-1005, 2012.

[18] X. Han, H. Ma, and Y. Wang, "p-TsOH catalyzed synthesis of 2-arylsubstituted benzimidazoles," Arkivoc, vol. 2007, no. 13, pp. 150-154, 2007.

[19] D. H. Boschelli, W. A. Denny, A. M. Doherty et al., "Benzimidazoles for inhibiting protein tyrosine mediated cellular proliferation," US patent, 6, 218, $388 \mathrm{~B} 1,2001$.

[20] R. R. Nagawade and D. B. Shinde, " $\mathrm{TiCl}_{4}$ promoted synthesis of benzimidazole derivatives," Indian Journal of Chemistry $B$, vol. 46, no. 2, pp. 349-351, 2007.

[21] A. W. Addison and P. J. Burke, "Synthesis of some imidazoleand pyrazole- derived chelating agents," Journal of Heterocyclic Chemistry, vol. 18, no. 4, pp. 803-805, 1981.

[22] G. Navarrete-Vázquez, H. Moreno-Diaz, F. Aguirre-Crespo et al., "Design, microwave-assisted synthesis, and spasmolytic activity of 2-(alkyloxyaryl)-1H-benzimidazole derivatives as constrained stilbene bioisosteres," Bioorganic \& Medicinal Chemistry Letters, vol. 16, no. 16, pp. 4169-4173, 2006. 


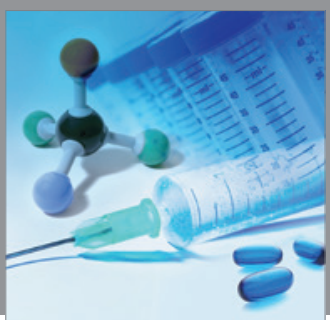

International Journal of

Medicinal Chemistry

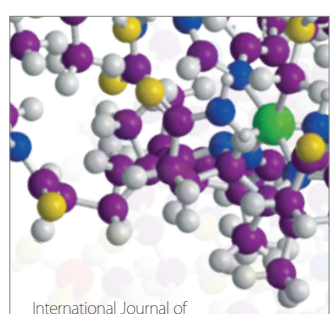

Carbohydrate Chemistry

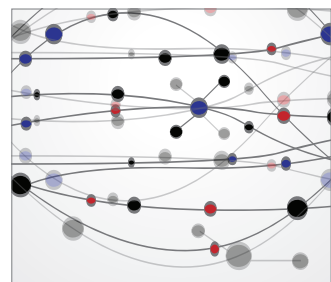

The Scientific World Journal
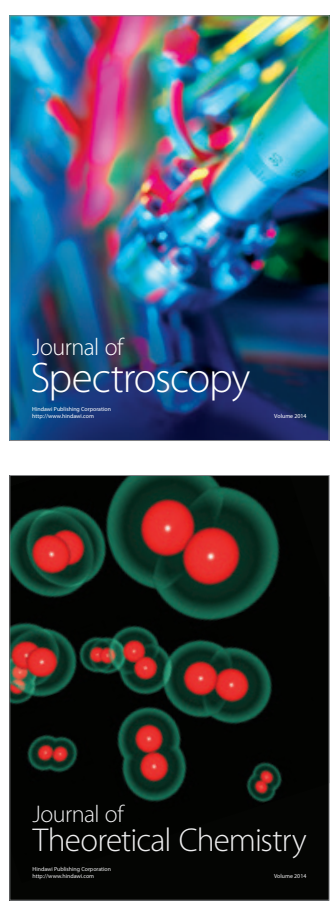
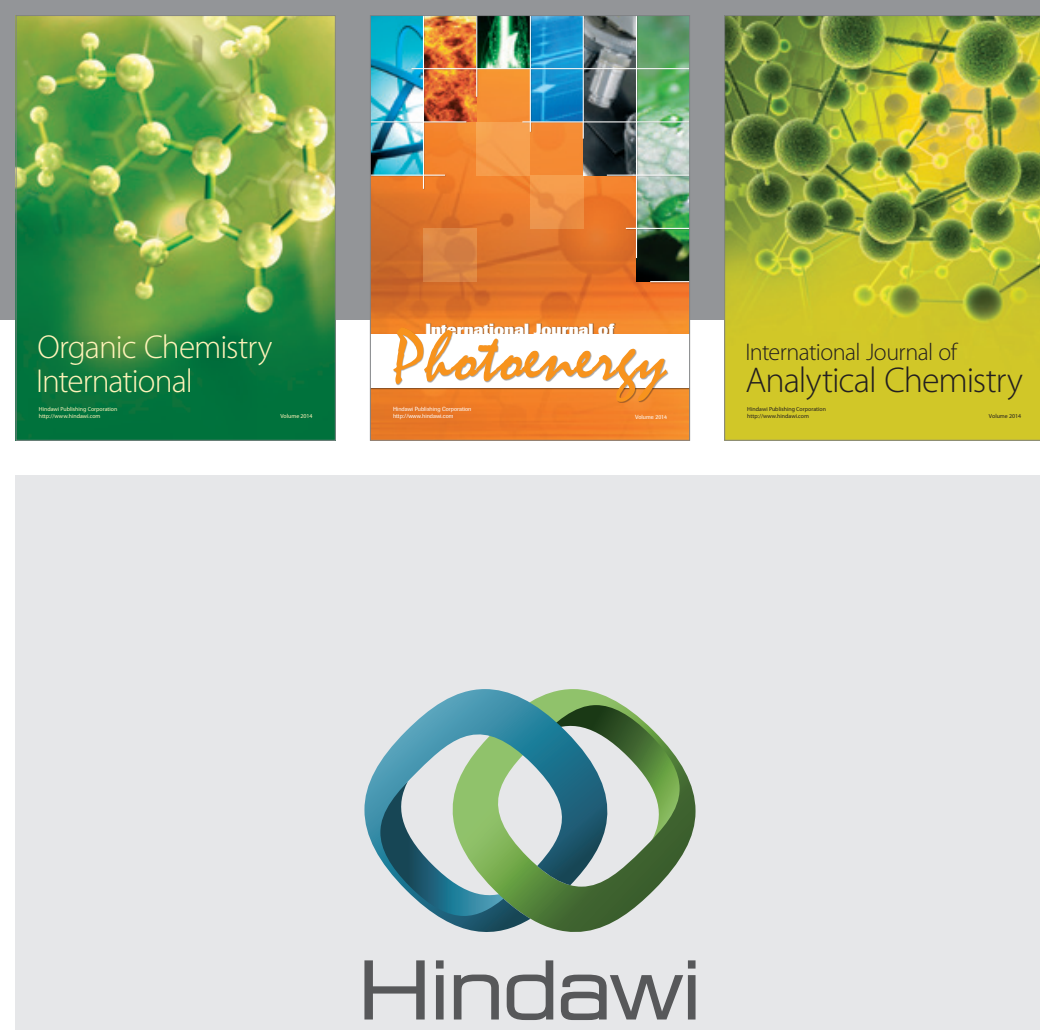

Submit your manuscripts at

http://www.hindawi.com
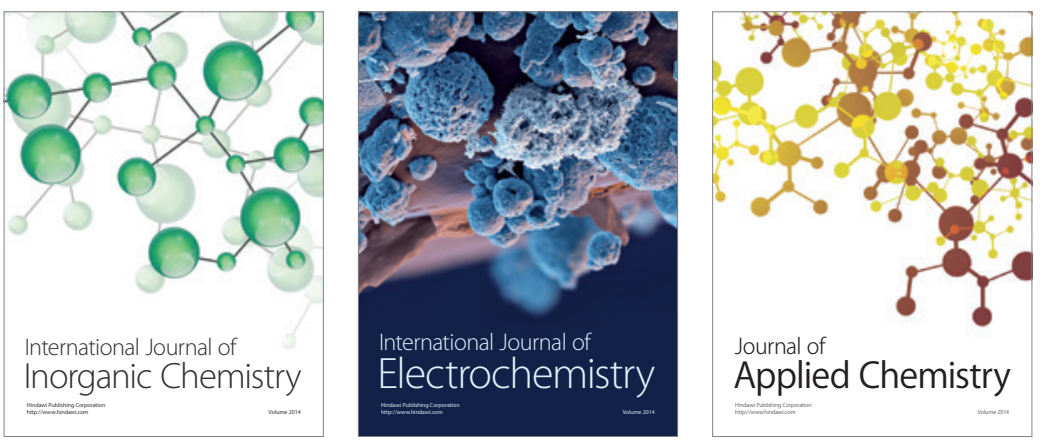

Journal of

Applied Chemistry
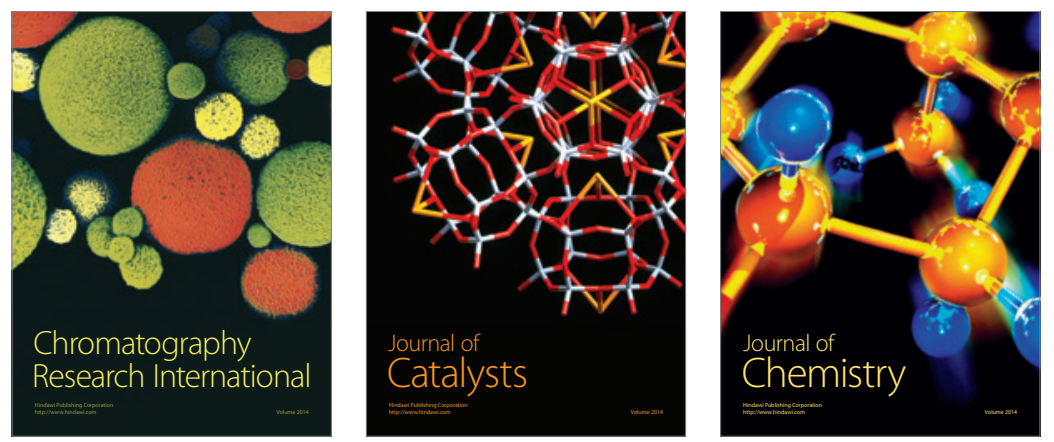
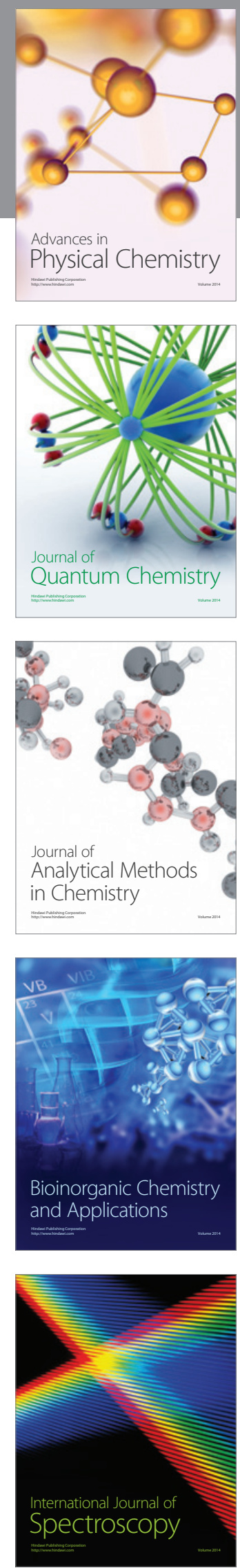